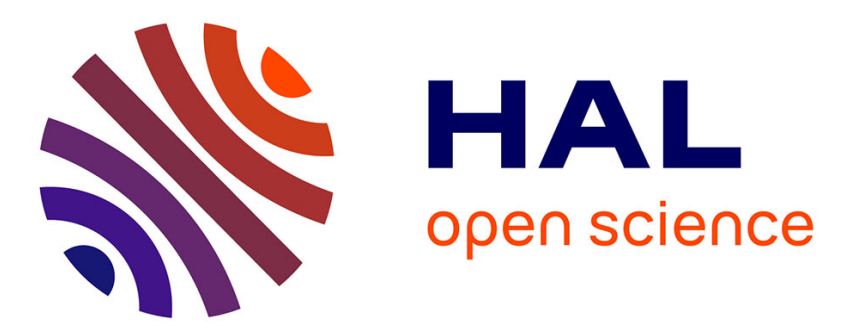

\title{
Introduction to the thematic volume: issues in landslide process monitoring and understanding
}

\author{
Jean-Philippe Malet, Christophe Delacourt, O. Maquaire, D. Amitrano
}

\section{To cite this version:}

Jean-Philippe Malet, Christophe Delacourt, O. Maquaire, D. Amitrano. Introduction to the thematic volume: issues in landslide process monitoring and understanding. Bulletin de la Société Géologique de France, 2007, 178 (2), pp.63 à 64. 10.2113/gssgfbull.178.2.63 . insu-00347208

\section{HAL Id: insu-00347208 \\ https://hal-insu.archives-ouvertes.fr/insu-00347208}

Submitted on 5 Mar 2021

HAL is a multi-disciplinary open access archive for the deposit and dissemination of scientific research documents, whether they are published or not. The documents may come from teaching and research institutions in France or abroad, or from public or private research centers.
L'archive ouverte pluridisciplinaire HAL, est destinée au dépôt et à la diffusion de documents scientifiques de niveau recherche, publiés ou non, émanant des établissements d'enseignement et de recherche français ou étrangers, des laboratoires publics ou privés. 


\title{
Introduction to the thematic volume Issues in landslide process monitoring and understanding: an introduction.
}

\author{
JEAN-PHILIPPE MALET ${ }^{1}$, CHRISTOPHE DELACOURT $^{2}$, OLIVIER MAQUAIRE $^{1}$, \\ et DAVID AMITRANO ${ }^{3}$
}

1. 'Laboratoire de Géographie Physique et de l'Environnement' (LETG-Geophen), UMR 6554 CNRSUCBN, Esplanade de la Paix, F-14032 Caen Cedex, France. Tel. +33(0)231565 608 / Fax. +33 (0)231 566384 / E-mail : jean-philippe.malet@unicaen.fr

2. 'Domaines Océaniques' UMR 6538 CNRS-IUEM-UBO, Place Copernic, F-29280, Plouzané, France.

3. 'Laboratoire Interdisciplinaire de Recherche Impliquant la Géologie et la Mécanique' (LIRIGM), EA 3111 UJF, Maison des Géosciences, BP 53, F-38041 Grenoble Cedex 9, France.

\section{SPECIAL NATURE OF LANDSLIDES, AND THE FRENCH 'SAMOA' PROJECT}

All mountainous countries have been exposed to slope movements throughout their history, reaching often disastrous dimensions. A significant increase in damage effects had to be recognised within the last two decades. The reasons for this steady increase in damage are often relayed on a probable impact of climate change. But people contribute also to, and even may exacerbate, or modify the hazard. The increase of our living standards, the concentration of people, infrastructure and goods at economically privileged but probably hazardous places, additional settlements in disaster prone regions and the enormous increase in mobility on road and train have to be considered as well. The number of victims and the cost of the damage may be high, depending on the duration, spatial extension and magnitude of the processes, and on the vulnerability of the exposed environment.

Even though considerable advances in the last decade have been gained in landslide process understanding (landslide databases and event catalogues, monitoring techniques, investigation tools), there are a series of gaps that should be filled in existing knowledge in order to apply this knowledge for longterm development of the mountain territories and safety of the citizens. This is mainly the consequence of the large kinematic variability of slope movements (slide, flow, fall, spreading) which are dynamic systems, complex in time and space and closely linked to both inherited and current preparatory and triggering controls.

To develop comprehensive hazard assessment procedures, it is therefore important to incorporate time series, 3-D patterns and deformation analyses in the model-building exercise; it is also essential that the physically-based models be improved so that a greater spatial and temporal description can be included. This goal requires first that rapid-varying factors (rainfall, freeze-thaw, meltwater, ground acceleration) and slow-varying factors (tectonic movements, weathering and associated property changes, erosion, deposition, changing confinement and unloading) are properly specified at adequate spatial and temporal resolutions. The influence of these elementary factors for the different landslide types can be identified through new investigation and monitoring techniques, and detailed analyses of event databases.

This special issue of 'Bulletin de la Société Géologique de France' contains eight contributions associated to the French National Project ACI CatNat 'Samoa' (Surveillance et auscultation des mouvements gravitaires alpins) coordinated by C. Delacourt, O. Maquaire \& D. Amitrano over the period 
2003-2005. The project consortium was composed of eight research institutes (Laboratoire de Sciences de la Terre, LST, Lyon; Institut de Physique du Globe de Strasbourg, IPGS, Strasbourg; Laboratoire Environnement, Géomécanique et Ouvrages, Laego, Nancy ; Laboratoire de Géophysique Interne et de Tectonophysique, LGIT, Grenoble ; GeoSciences Azur, Nice ; Laboratoire Interdisciplinaire de Recherche Impliquant la Géologie et la Mécanique, Lirigm, Grenoble ; Laboratoire d'Hydrogéologie de l'Université d'Avignon, LHA, Avignon ; Bureau des Recherches Géologiques et Minières, BRGM, Orléans).

The goals of this project were:

(1) to federate the French community working on landslide characterization and monitoring using remote-sensing, geophysics, geo- and hydrochemistry, hydrology, geotechnics and geomorphology;

(2) to elaborate and test quantitative investigation methods of spatial and temporal heterogeneities of landslides;

(3) to elaborate multiscale protocols suitable to the investigation of several landslide types (rock- and soil-type landslide);

(4) to initiate and extent the collection of multi-source data on some reference sites in terms of geometry, temporal and spatial kinematics, internal structure, rheology and hydrology.

Two reference sites have been chosen in order to cover the main types of landslides: one in hard rocks (La Clapière rockslide) and one in soft (reworked) mudrocks (Super-Sauze mudslide). The 3D geometry of the landslides has been investigated by combining various geophysical and remote-sensing data. The multiscale (spatial and temporal) strain fields were analysed from 0.1 second to some years by seismic and remote-sensing methods. The residence time and the origin of water circulating within the landslides were determined from geo- and hydro-chemical data. These techniques are now operational and can be applied to other landslides. The databases are available for the French research community.

\section{THE PRESENT VOLUME}

The present volume of 'Bulletin de la Société Géologique de France' brings together a number of studies where landslide characterization and monitoring have allowed to progress in the understanding of landslide mechanisms. State-of-the-art papers are also included in order to synthesize existing knowledge available for landslide hazard assessment. These papers might be regarded as a time-slice, showing us age around 2006. The present collection of papers makes a significant contribution to bringing together the ideas of geophysicians, hydrologists and geomorphologists. Techniques used in these studies for description and analyses are by no means uniform, and if standardisation is desirable there is still a long way to go.

In the introductory paper, Van Asch et al. review the state-of-the-art in the understanding of landslide processes and identify some pressing challenges for the development of modelling capabilities for hazard assessment. Their paper focuses on the special nature of slope movements and the difficulties related to simulating their complex time-dependent behaviour in mathematical, physically-based, models. It analyses successively the research frontiers in the recognition of first-time failures (pre-failure and failure stages), reactivation and the catastrophic transition to rapid gravitational processes (post-failure stage). Subsequently, the paper discusses avenues to transfer local knowledge on landslide activity to landslide hazard forecasts on regional scales.

Delacourt et al. are concerned with the characterization of landslide surface displacements and review the techniques of image analysis (interferometry and optical data correlation). Examples of applications of these techniques in French South Alps are shown. Depending on the landslide characteristics (exposure conditions, size, velocity) as well as the goal of the study (operational or scientific purpose), one or a combination of several techniques and data (characterized by several resolution, accuracy, covered surface, revisiting time) have to be used. The authors demonstrate that investigating landslide surface displacement is a key parameter to access to their geometries and mechanical properties.

Jongmans \& Garambois present a current state-of-the-art on the application of surface geophysical methods (2D, 3D and even 4D) to landslide characterization, showing both their interest and their limits. 
The authors emphasized the geophysical image characteristics (resolution, penetration depth) which have to be provided for assessing their reliability, as well as the absolute requirements to combine geophysical methods and to calibrate them with existing geological and geotechnical data. They stressed also the link to establish between physical parameters derived from geophysics and the geological and mechanical properties required by geologists and engineers.

Bogaard et al. give an overview of the potential hydrogeochemistry can have for landslide research and analyse the use of hydrogeochemical information to unravel the hydrological processes in landslide triggering. The authors stress the impact hydrogeochemistry has on physical properties of the soil and rock material, and investigate how the identification of the origin of water, the flow paths, the travel times and the soil chemical information are environmental characteristics of paramount importance to identify contribution of different aquifers to the landslide area.

Grandjean et al. combine several geophysical methods (acoustic P-wave velocity and shear S-waves velocity, $\rho$ electrical resistivity) to investigate the structure and rheology of a mudslide. The authors show a correlation between the seismic velocities and electrical resistivity data, confirming that the simultaneous use of both methods gives complementary information: the seismic data provide information on the variations of fissure density and on the presence of deformed material whereas the electrical resistivity data provide information on the variations of water content within the mudslide. A data fusion strategy based on fuzzy subsets theory is developed. The computed fuzzy cross-sections show the possibility of geomechanical hypotheses to be realized in specific areas of the mudslide, and highlight the places where plastic or solid-body deformations could occur.

Méric et al. present a paper on the use of seismic noise based methods to better understand the mechanics and dynamics of two clayey landslides. Their investigations were composed of seismic profiles for surface wave inversions, $\mathrm{H} / \mathrm{V}$ measurements in order to image shear wave contrasts (slip surfaces), and seismic noise array measurements to provide S-waves velocity profile versus depth. Comparison between the geophysical investigations and geotechnical data proved the applicability of such passive methods in 3D complex structures, and particularly for landslides difficult to access. Indeed, these passive methods require lighter instrumentation and easier processing tools.

Amitrano et al. presents seismic monitoring data acquired on a mudslide, and show that recordable seismicity exists in the frequency range of $0.01 \mathrm{~Hz}$ to $10 \mathrm{~Hz}$ associated with landslide deformation. The origin of the seismicity is attributed to shearing of the moving mass at the interface with an in-situ stable bedrock. Spectral analysis of the seismic wave reveals that the range $0.1-1 \mathrm{~Hz}$ is the most sensitive to the variations in landslide velocity. The results emphasize the strong potential of seismic monitoring for improving our understanding of mechanisms controlling rock mass deformation and gravitational instability.

Binet et al. determine the long-term relationships between groundwater and gravitational instabilities in a landslide prone region of the South French Alps. The authors propose a conceptual model of water flow within unstable rocky slopes using water chemistry and flow records. Variations in infiltrated yield, flow velocity and porosity are observed and linked to collapsed and toppled structures in the upper parts of the hillslopes.

In this assemblage of papers, the sum is larger than the parts, and the collection reveals the range of techniques, processing tools and models, and current ideas on the study of slope movements in a wide range of geomorphic settings, and the benefit of geophysical, geotechnical, hydrochemical and engineering techniques in applied geomorphology.

Jean-Philippe Malet, Dr. CNRS, UMR 6554, University of Caen-Basse-Normandie, Caen, France E-mail address: jean-philippe.malet@unicaen.fr. Corresponding author. 
CNRS, UMR 6538 IUEM-DO, University of Brest, Brest, France. E-mail address: christophe.delacourt@univ-brest.fr.

Olivier Maquaire, Prof. CNRS, UMR 6554, University of Caen-Basse-Normandie, Caen, France E-mail address: olivier.maquaire@unicaen.fr.

David Amitrano, Dr. CNRS, UMR 5559 LGIT, University Joseph Fourier, Grenoble, France E-mail address: david.amitrano@ujf-grenoble.fr. 